\title{
Lung function monitoring in patients with duchenne muscular dystrophy on steroid therapy
}

\author{
Darlene L Machado ${ }^{1}$, Elaine C Silva', Maria B D Resende ${ }^{1}$, Celso R F Carvalho², \\ Edmar Zanoteli ${ }^{1,3}$ and Umbertina $C$ Reed $^{1 *}$
}

\begin{abstract}
Background: Duchenne muscular dystrophy (DMD) is a sex-linked inherited muscle disease characterized by a progressive loss in muscle strength and respiratory muscle involvement. After 12 years of age, lung function declines at a rate of $6 \%$ to $10.7 \%$ per year in patients with DMD. Steroid therapy has been proposed to delay the loss of motor function and also the respiratory involvement.

Method: In 21 patients with DMD aged between seven and 16 years, the forced vital capacity (FVC) and the forced expiratory volume in one second $\left(\mathrm{FEV}_{1}\right)$ were evaluated at three different times during a period of two years.

Results: We observed in this period of evaluation the maintenance of the FVC and the $F E V_{1}$ in this group of patients independently of chronological age, age at onset of steroid therapy, and walking capacity.

Conclusion: The steroid therapy has the potential to stabilize or delay the loss of lung function in DMD patients even if they are non-ambulant or older than 10 years, and in those in whom the medication was started after 7 years of age.
\end{abstract}

Keywords: Duchenne muscular dystrophy, Steroids, Vital forced capacity, Respiratory function tests, Myopathies

\section{Background}

Duchenne muscular dystrophy (DMD) is one of the most common inherited pediatric neuromuscular disorders, affecting 1 in 3,500 live male births. It is an $\mathrm{X}$-linked disorder caused by mutations in the dystrophin gene and is characterized by a progressive decrease in muscle strength and motor function $[1,2]$. Besides the impairment of motor function, one major problem is the progressive involvement of the respiratory muscles which leads to secondary changes such as atelectasis, decreased lung compliance, ineffective cough and occurrence of repeated infections, as well as imbalance in ventilation-perfusion and hypoxia during sleep [3,4].

Patients with DMD develop a restrictive respiratory pattern with reduction of maximal respiratory pressures and forced vital capacity (FVC) that implicates a risk for respiratory failure and death [2,5]. Consequently,

\footnotetext{
* Correspondence: ucontireed@hcnet.usp.br

'Department of Neurology, Medical School of the University of São Paulo, Av. Dr. Enéas de Carvalho Aguiar 255, room 5131, Cerqueira Cesar, São Paulo 05403900, Brazil

Full list of author information is available at the end of the article
}

measures of lung function are fundamental methods to monitor the outcome of patients [6]. Pulmonary function of patients with DMD increases until the age of 10 to 12 years and then reaches a plateau. This increase reflects the growth of the entire rib cage, including its muscles and ligaments [7,8]. Following the plateau phase, lung function declines at a rate of 6-8 \% annually [6-10]. A recent study shows a decrease of vital capacity of $10.7 \%$ per year in patients with DMD [11].

Steroid therapy has been used to slow the progression of the disease with many studies showing a delay in motor impairment from six months to three years [1216]. Although it is still uncertain how long steroids can slow the progression of respiratory impairment, retrospective studies of long-term monitoring in patients with DMD have documented the maintenance of lung function for a long period $[14,15]$. The aim of our study was to evaluate longitudinally the pulmonary function in DMD patients on steroid therapy and its relation to age, motor ability (ambulant or not), and age at the onset of steroid therapy.

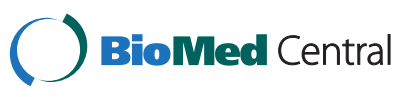

(c) 2012 Machado et al.; licensee BioMed Central Ltd. This is an Open Access article distributed under the terms of the Creative Commons Attribution License (http://creativecommons.org/licenses/by/2.0), which permits unrestricted use, distribution, and reproduction in any medium, provided the original work is properly cited. 


\section{Methods}

\section{Study design}

We evaluated 30 boys with DMD who were between seven and 23 years of age. The diagnosis of DMD was confirmed by molecular analysis and/or by imunohistochemistry and Western blot of dystrophin in muscle biopsy. All children were being treated with deflazacort $(0.9 \mathrm{mg} / \mathrm{kg} /$ day once daily) or prednisolone $(0.75 \mathrm{mg} / \mathrm{kg}$ per day intermittently 10 days on/10 days off). A control group was not included in this study because most of our patients had submitted to steroid treatment. Patients were excluded from the study in the following circumstances: tracheotomy, smokers, respiratory infection or other pulmonary diseases, and discontinuation of the steroid therapy during the study. The term of consent was signed by the parents and approved by the Ethics Committee for Analysis of Research Projects of our Institution.

Patients were classified according to the age of evaluation [10 years of age or younger ( $\leq 10$ years), and older than 10 years of age ( $>10$ years)], age of onset of steroid therapy [seven years of age or younger ( $\leq 7$ years), and older than seven years of age ( $>7$ years)] and walking capacity (ambulant and non-ambulant). The height of ambulant patients was measured in a standing position, with correction of the equines support when possible; when not, height was estimated using the length of the arm span. The tests were performed by the same physiotherapist using a spirometer (microQuark, Cosmed, Italy) coupled to a microcomputer with daily calibration. Three evaluations were performed, all on the days of regular medical appointments. The patients were assessed initially at the first evaluation; and the second and third evaluations, respectively, were performed one and two years later.

\section{Pulmonary function testing}

Measurements were performed with the patient in the sitting position, following the recommendations of the American Thoracic Society and the European Respiratory Society (ATS/ERS) [17]. Up to eight tests were performed, with an interval of rest of one minute or more (if necessary). We selected the three best performances with a maximum variability of $5 \%$ or $200 \mathrm{ml}$ between them. The parameters evaluated were FVC and forced expiratory volume in $1 \mathrm{sec}\left(\mathrm{FEV}_{1}\right)$, both expressed as absolute and relative values. The relative values were obtained by comparison with normal values for all spirometric variables [18]. Statistical analysis was performed using the analysis of variance (ANOVA) with repeated measures to compare the average results obtained in the groups of patients (group effect) and among the three different periods of evaluation (time effect). When the covariance matrix of the observations of the same individual was not found, the tests were adjusted based on Huynh-Feldt correction. An index of significance of $5 \%(\mathrm{p}<0.05)$ was adopted and it was verified if there was interaction among the results.

\section{Results}

Of the 30 patients who were evaluated initially, only 21 were monitored for the entire period of two years. Patients were excluded because they failed to use medication regularly or because they failed to attend the evaluations. The age of the 21 patients that concluded the study varied from 7 to 16 years. The mean age of the first recording was $11.6 \pm 3$ years. The mean height and weight, respectively, were $142.8 \pm 15.0 \mathrm{~cm}$ and $35.6 \pm 9.1 \mathrm{~kg}$ at the first evaluation and $147.8 \pm 14.2 \mathrm{~cm}$ and $40.7 \pm 9.5 \mathrm{~kg}$ at the last visit. The mean body mass index was $17.5 \pm 3.4$ at the first evaluation and $18.7 \pm 3.6$ at the last visit. The average age at the loss of walking capacity was $10.7 \pm 2.7$ years. None patient had been submitted to spinal surgery, most of the patients (86\%) attended physiotherapy sections and a small proportion of them (24\%) also attended respiratory therapies. Seven patients (33\%) performed an air stacking maneuver at home and during physical therapy sessions and two (10 \%) utilized non-invasive ventilation (NIV) at night. The average age of onset of steroid therapy was $8.05 \pm 3.06$. Ten patients $(48 \%)$ started the medication with $\leq 7$ years and 11 (52\%) after this age. Only two patients started the drug after the loss of walking capacity. One was 16 years old and initially had absolute and relative values of FVC of $0.4 \mathrm{~L}$ and $36.9 \%$, respectively, and at the last visit, $0.89 \mathrm{~L}$ and $34.7 \%$, respectively. The other was 15 years old and initially showed absolute and relative values of FVC of $1.33 \mathrm{~L}$ and $43.6 \%$, respectively, and $1,43 \mathrm{~L}$ and $54.9 \%$, respectively, at the end of follow up.

In relation to the three times of evaluation, the FVC and $\mathrm{FEV}_{1}$ expressed in absolute and relative values showed no statistically significant change either in patients $\leq 10$ years or those older than 11 years (Tables 1 and 2, Figure 1 and 2). Also, in patients who started the steroid therapy with $\leq 7$ years and after of this age, as well as in ambulant and non-ambulant patients, no significant changes were observed (Tables 1 and 2). Comparing the groups of patients according to age ( $\leq 10$ years and $>10$ years), age of onset of therapy ( $\leq 7$ years and $>7$ years), and walking capacity (ambulant and non-ambulant), lung function did not show any statistically significant differences $(p>0.05)$. In addition, interaction in the results of each group tested was not observed (Tables 1 and 2).

\section{Discussion}

Our study demonstrated the maintenance of lung function for a period of up to two years in patients with 
Table 1 Forced Vital Capacity (FVC) in three times of evaluation according to the age ( $\leq 10$ years and $>10$ years), age of onset of steroid therapy ( $\leq 7$ years and $>7$ years), and walking capacity (ambulant and non-ambulant)

\begin{tabular}{|c|c|c|c|c|}
\hline & & FVC (L/\%) & & \\
\hline & $\begin{array}{c}\text { Evaluation } \\
\text { I }\end{array}$ & $\begin{array}{c}\text { Evaluation } \\
\text { II }\end{array}$ & $\begin{array}{c}\text { Evaluation } \\
\text { III }\end{array}$ & \\
\hline $\begin{array}{c}\text { Age ( } \leq 10 \text { years }) \\
n=9\end{array}$ & $\begin{array}{l}1.6 \pm 0.3 / \\
78.8 \pm 12.5\end{array}$ & $\begin{array}{l}1.7 \pm 0.4 / \\
80.1 \pm 16.6\end{array}$ & $\begin{array}{l}1.7 \pm 0.4 / \\
75.2 \pm 20.2\end{array}$ & $\begin{array}{l}p^{1}=0.24 / 0.59 \\
p^{2}=0.07 / 0.31\end{array}$ \\
\hline $\begin{array}{c}\text { Age (>10 years) } \\
n=12\end{array}$ & $\begin{array}{l}1.7 \pm 0.4 / \\
66 \pm 22.1\end{array}$ & $\begin{array}{l}1.8 \pm 0.4 / \\
65.5 \pm 24.7\end{array}$ & $\begin{array}{l}1.7 \pm 0.4 / \\
60.5 \pm 23.6\end{array}$ & $p^{3}=0.19 / 0.09$ \\
\hline $\begin{array}{c}\text { Age of onset of steroid } \\
\text { therapy ( } \leq 7 \text { years) }\end{array}$ & $\begin{array}{l}1.6 \pm 0.3 / \\
75.9 \pm 16.3\end{array}$ & $\begin{array}{l}1.7 \pm 0.5 / \\
78.5 \pm 22.5\end{array}$ & $\begin{array}{l}1.7 \pm 0.4 / \\
74.7 \pm 25.5\end{array}$ & $\begin{array}{l}p^{1}=0.24 / 0.61 \\
p^{2}=0.05 / 0.25 \\
p^{3}=0.21 / 0.23\end{array}$ \\
\hline$n=10$ & & & & \\
\hline $\begin{array}{c}\text { Age of onset of steroid } \\
\text { therapy (>7 years) } \\
\quad n=11\end{array}$ & $\begin{array}{l}1.7 \pm 0.4 / \\
66.9 \pm 21.3\end{array}$ & $\begin{array}{l}1.8 \pm 0.4 / \\
66.1 \pm 21.7\end{array}$ & $\begin{array}{l}1.7 \pm 0.3 / \\
59.6 \pm 18.5\end{array}$ & \\
\hline Ambulant & $\begin{array}{l}1.7 \pm 0.4 / \\
86.2 \pm 10.6\end{array}$ & $\begin{array}{l}1.9 \pm 0.4 / \\
92.3 \pm 11.5\end{array}$ & $\begin{array}{l}1.9 \pm 0.3 / \\
87.2 \pm 15.6\end{array}$ & $\begin{array}{l}p^{1}=0.37 / 0.65 \\
p^{2}=0.41 / 0.99\end{array}$ \\
\hline$n=9$ & & & & $p^{3}=0.83 / 0.67$ \\
\hline $\begin{array}{c}\text { Non-ambulant } \\
n=12\end{array}$ & $\begin{array}{l}1.6 \pm 0.4 / \\
60 \pm 16.3\end{array}$ & $\begin{array}{l}1.6 \pm 0.4 / \\
56.7 \pm 15.1\end{array}$ & $\begin{array}{l}1.5 \pm 0.3 / \\
51.5 \pm 13.3\end{array}$ & \\
\hline
\end{tabular}

Table legend: $\mathrm{p}^{1}=$ comparison between the three evaluations, $\mathrm{p}^{2}=$ comparison between both groups, $\mathrm{p}^{3}=$ interaction effect.

DMD treated with steroids regardless of age, walking capacity, and age of onset of therapy. We were not able to confirm that steroid therapy alone is responsible for the maintenance of lung function, due to the lack of a control group. According to McDonald et al., [9] the loss of walking ability and spinal deformities can affect lung function but age is the most important factor. Regarding age, we have detected that in patients older than 10 years, lung function was maintained without significant changes during a period of up to two years, while in the natural history of disease, lung volumes typically decline about $6 \%$ to $10.7 \%$ per year after 10 years of

Table 2 Forced Expiratory Volume in $1 \mathrm{sec}\left(\mathrm{FEV}_{1}\right)$ in three times of evaluation according to the age ( $\leq 10$ years and $>10$ years), age of onset of steroid therapy ( $\leq 7$ years and $>7$ years), and walking capacity (ambulant and non-ambulant)

\begin{tabular}{|c|c|c|c|c|}
\hline & & $\mathrm{FEV}_{1}(\mathrm{~L} / \%)$ & & \\
\hline & $\begin{array}{c}\text { Evaluation } \\
\text { I }\end{array}$ & $\begin{array}{c}\text { Evaluation } \\
\text { II }\end{array}$ & $\begin{array}{c}\text { Evaluation } \\
\text { III }\end{array}$ & \\
\hline Age ( $\leq 10$ years) & $\begin{array}{l}1.3 \pm 0.3 / \\
72.5 \pm 17.14\end{array}$ & $\begin{array}{l}1.5 \pm 0.5 / \\
77.4 \pm 20.8\end{array}$ & $\begin{array}{l}1.3 \pm 0.4 / \\
69.1 \pm 22\end{array}$ & $p^{1}=0.35 / 0.43$ \\
\hline$n=9$ & & & & $p^{2}=0.16 / 0.17$ \\
\hline Age ( $>10$ years) & $\begin{array}{l}1.5 \pm 0.4 / \\
64.3 \pm 20.6\end{array}$ & $\begin{array}{l}1.5 \pm 0.3 / \\
64.5 \pm 22.5\end{array}$ & $\begin{array}{l}1.5 \pm 0.3 / \\
61.8 \pm 22.3\end{array}$ & $p^{3}=0.13 / 0.16$ \\
\hline$n=12$ & & & & \\
\hline Age of onset of steroid & $1.3 \pm 0.3 /$ & $1.5 \pm 0.5 /$ & $1.4 \pm 0.5 /$ & $p^{1}=0.32 / 0.38$ \\
\hline & & & & $p^{2}=0.05 / 0.22$ \\
\hline$n=10$ & & & & $p^{3}=0.18 / 0.18$ \\
\hline $\begin{array}{l}\text { Age of onset of steroid } \\
\text { therapy ( }>7 \text { years) }\end{array}$ & $\begin{array}{l}1.5 \pm 0.4 / \\
64.3 \pm 19.6\end{array}$ & $\begin{array}{l}1.5 \pm 0.3 / \\
64.3 \pm 19\end{array}$ & $\begin{array}{l}1.4 \pm 0.2 / \\
58.5 \pm 15.2\end{array}$ & \\
\hline$n=11$ & & & & \\
\hline Ambulant & $1.4 \pm 0.3 /$ & $1.6 \pm 0.4 /$ & $1.6 \pm 0.3 /$ & $p^{1}=0.42 / 0.41$ \\
\hline & $80.4 \pm 13.9$ & $87.8 \pm 15.9$ & $82.1 \pm 19.1$ & $p^{2}=0.18 / 0.98$ \\
\hline$n=9$ & & & & $p^{3}=0.50 / 0.38$ \\
\hline Non-ambulant & $1.4 \pm 0.4 /$ & $1.4 \pm 0.4 /$ & $1.3 \pm 0.3 /$ & \\
\hline$n=12$ & $58.3 \pm 17.5$ & $56.7 \pm 16.1$ & $52.2 \pm 13.9$ & \\
\hline
\end{tabular}

Table legend: $\mathrm{p}^{1}=$ comparison between the three evaluations, $\mathrm{p}^{2}=$ comparison between both groups, $\mathrm{p}^{3}=$ interaction effect. 


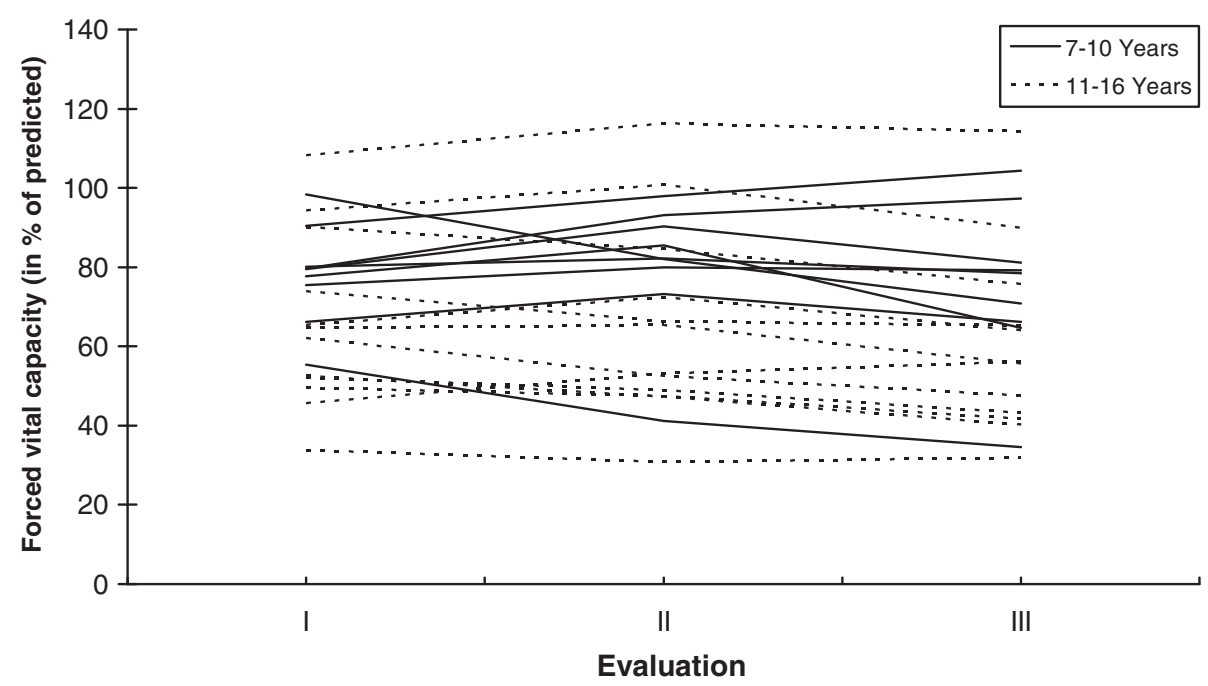

Figure 1 Individual values of Forced Vital Capacity (FVC) were expressed in \% of the predicted value. After the Evaluation I (baseline), patients were followed yearly (evaluations II and III). Patients were divided in 2 groups according their age (7-10 years and 11-16 years).

age [6,9-11]. This finding clearly demonstrated the efficacy of the steroid therapy in delaying respiratory deterioration in these patients, even when they are older than 10 years of age.

Steroids conventionally are used in order to increase the walking period. However, some authors have suggested that the treatment should be continued in wheelchair patients due to the potential effect of the medication in preventing spinal deformity and the deterioration of respiratory function [15,19-21]. In our study, both wheelchair-bound patients and ambulant patients showed stability of the respiratory parameters, which demonstrates the maintenance of lung function in steroid-treated patients, even after the loss of walking capacity.

The optimal age to begin steroid treatment in order to preserve respiratory function is poorly defined. In theory, the use of the steroids at the initial stages of the disease could prevent the development of disabilities, including the deterioration of lung function. We evaluated respiratory function in patients who started steroid therapy $\leq 7$ years and $>7$ years of age in order to verify the possible influence of the age of onset of therapy on the evolution of lung function. Both groups showed

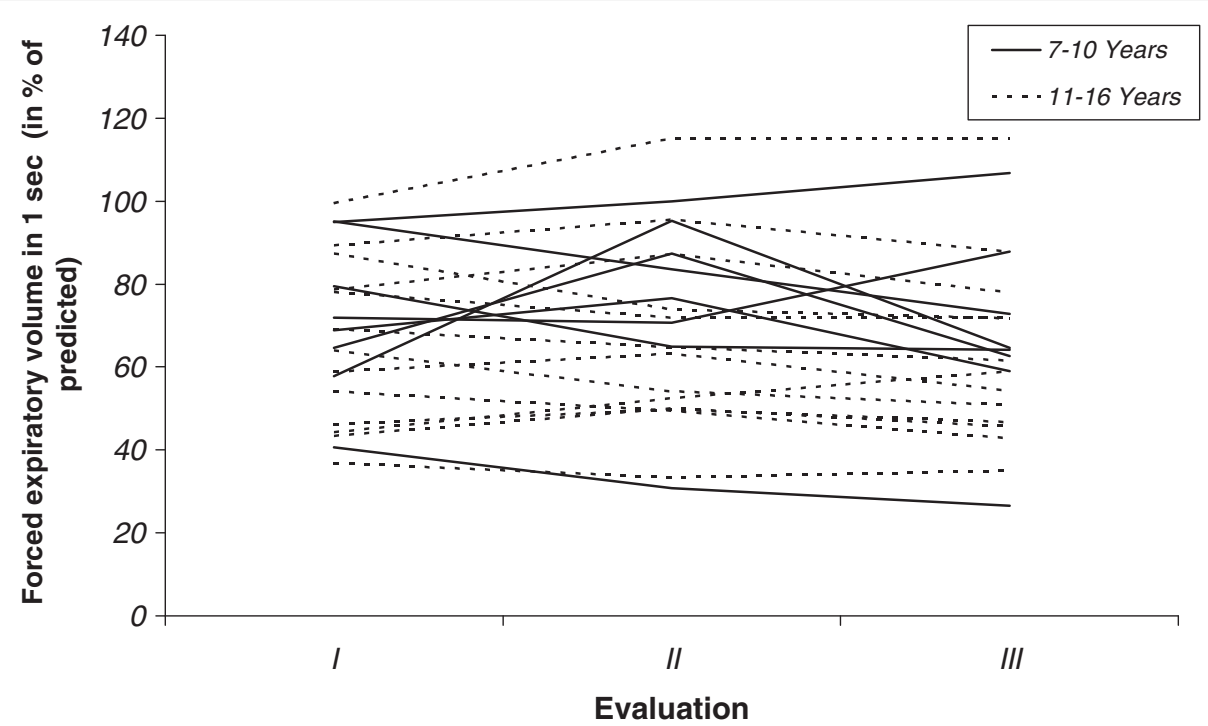

Figure 2 Individual values of Forced Expiratory Volume in $1 \mathrm{sec}\left(\mathrm{FEV}_{\mathbf{1}}\right)$ were expressed in \% of the predicted value. After the Evaluation I (baseline), patients were followed yearly (evaluations II and III). Patients were divided in 2 groups according their age (7-10 years and 11-16 years). 
stability of FVC and $\mathrm{FEV}_{1}$, which indicates that steroid treatment might stabilize lung function even in those children who are first treated when they are older than 7 years of age. Longer follow-up is necessary to clarify the best time to start the medication.

Although not as sensitive as the maximum inspiratory pressure (MIP) and maximum expiratory pressure (MEP), FVC and $\mathrm{FEV}_{1}$ give good information on the reduction of pulmonary compliance and chest wall dynamic, which reflects the state of the bronchi and requiring muscle power to obtain maximum values. Therefore, FVC and $\mathrm{FEV}_{1}$ provide useful and reproducible measures of the progression of the disease $[3,6]$. Furthermore, $\mathrm{FEV}_{1}$ and MIP are strongly correlated $[10,11]$. Possibly, a longer follow-up would determine how long pulmonary function and respiratory muscle strength remain stable in DMD patients treated with steroids. Some of our patients performed the "air stacking" maneuver at home or during physiotherapy. However, we did not determine how frequently the maneuver was performed or the influence of the maneuver on pulmonary parameters. The "air stacking" maneuver is reported to have positive effects only in peak flow of cough and maximum insufflation capacity $[22,23]$. The CVF continued to decline independently of the use of this maneuver [23]. Only a small number of our patients used non-invasive ventilation (NIV) during sleep. Therefore, we could not analyze the effects of NIV.

This study present 2 limitations: first, the period of follow up may be considered short (2 years); however, most study evaluating the effect of corticosteroid in motor impairment in DMD patients have studied such period of time $[20,21]$. Second, the absence of control could represent a limitation; however, there are studies demonstrating that corticosteroid improves motor function in DMD patients and for ethical reasons a control group was considered inadequate by our hospital's ethical committee.

\section{Conclusion}

Our study has shown that steroid treatment has the potential to stabilize lung function in DMD patients even in non-ambulant children, in those older than 10 years and in those in which the medication was started after 7 years of age.

\section{Abbreviations}

DMD: Duchenne muscular dystrophy; FVC: Forced vital capacity; FEV ${ }_{1}$ : Forced expiratory volume in one second; MIP: Maximum inspiratory pressure; MEP: Maximum expiratory pressure; NIV: Non-invasive ventilation..

\section{Competing interests}

The authors declare that they have no competing interests.

\section{Authors' contribution}

DLM: study design and conception; data acquisition, analysis and interpretation; manuscript elaboration. ECS: data acquisition. MBDR: substantial contribution to study conception and data acquisition. CRFC: substantial contribution to study conception; data acquisition, analysis and interpretation. EZ and UCR: substantial contribution to study conception and data acquisition; manuscript elaboration; critical revision and approval of the manuscript final version. All authors read and approved the final manuscript.

\section{Acknowledgements}

DLM was supported by CAPES (Coordenação de Aperfeiçoamento Pessoal de Ensino Superior).

\section{Author details}

${ }^{1}$ Department of Neurology, Medical School of the University of São Paulo, Av. Dr. Enéas de Carvalho Aguiar 255, room 5131, Cerqueira Cesar, São Paulo 05403900, Brazil. ²Department of Physical Therapy, Speech Therapy and Occupational Therapy, Medical School of the University of São Paulo, São Paulo, Brazil. ${ }^{3}$ Neuromuscular Division, Associação de Assistência à Criança Deficiente (AACD), São Paulo, Brazil.

Received: 19 July 2012 Accepted: 31 July 2012

Published: 13 August 2012

\section{References}

1. Bushby K, Finkel R, Birnkrant DJ, Case LE, Clemens PR, Cripe L, Kaul A, Kinnett K, McDonald C, Pandya S, Poysky J, Shapiro F, Tomezsko J, Constantin C: DMD Care Considerations Working Group. Diagnosis and management of Duchenne muscular dystrophy, part 1: diagnosis, and pharmacological and psychosocial management. Lancet Neurol 2010, 9:77-93.

2. Bushby K, Finkel R, Birnkrant DJ, Case LE, Clemens PR, Cripe L, Kaul A, Kinnett K, McDonald C, Pandya S, Poysky J, Shapiro F, Tomezsko J, Constantin C: DMD Care Considerations Working Group. Diagnosis and management of Duchenne muscular dystrophy, part 2: implementation of multidisciplinary care. Lancet Neurol 2010, 9:177-189.

3. Smith PM, Calverley PM, Edwards RH, Evans GA, Campbell EJ: Practical problems in the respiratory care of patients with muscular dystrophy. N Engl J Med 1987, 316:1197-1205.

4. Alves SC, Resende MBD, Skomro RP, Sousa JFB, Reed UC: Sleep and neuromuscular disorders in children. Sleep Med Rev 2009, 13:133-148.

5. Hapke EJ, Meek JC, Jacobs J: Pulmonary function in progressive muscular dystrophy. Chest 1972, 61:41-47.

6. Tangsrud SE, Petersen IL, Carlsen $\mathrm{KCL}$, Carlsen $\mathrm{KH}$ : Lung function in children with Duchenne's muscular dystrophy. Respir Med 2001, 95 : 898-903.

7. Rideau Y, Jankowski LW, Grellet J: Respiratory Function in muscular dystrophies. Muscle Nerve 1981, 4:155-164.

8. Rideau Y: Prognosis of progressive muscular dystrophy in children. Analysis of early and exact criteria. Union Med Can 1977, 106:874-882.

9. McDonald CM, Abresch RT, Carter GT, Fowler WM Jr, Johnson ER, Kilmer DD, Sigford BJ: Profiles of neuromuscular diseases. Duchenne muscular dystrophy. Am J Phys Med Rehabil 1995, 74(Suppl 5):S70-S92.

10. Hahn AH, Bach JR, Delaubier A, Irani AR, Guillou C, Rideau Y: Clinical implications of maximal respiratory pressure determinations for individuals with Duchenne muscular dystrophy. Arch Phys Med Rehabilit 1997, 78:1-6.

11. Gayraud J, Ramonatxo M, Rivier F, Humberclaude V, Petrof B, Matecki S: Ventilatory parameters and maximal respiratory pressure changes with age in Duchenne Muscular Dystrophy patients. Pediatr Pulmonol 2010, 45:552-559.

12. Fenichel GM, Florence MD, Pestronk A, Mendell JR, Moxley RT 3rd, Griggs RC, Brooke MH, Miller JP, Robison J, King W: Long-term benefit from prednisone therapy in Duchenne muscular dystrophy. Neurology 1991, 41:1874-1877.

13. Connolly AM, Schierbecker J, Renna R, Florence J: High dose weekly oral predinisone improves strength in boys with Duchenne muscular dystrophy. Neuromuscul Disord 2002, 12:917-925.

14. Balaban B, Matthews DJ, Clayton GH, Carry T: Costicosteroid treatment and functional improvement in Duchenne muscular dystrophy: long term effect. Am J Phys Med Rehabil 2005, 84:843-850.

15. Biggar WD, Harris VA, Eliasoph L, Alman B: Long-term benefits of deflazacort treatment for boys with Duchenne muscular dystrophy in their second decade. Neuromuscul Disord 2006, 16:249-255. 
16. Parreira SL, Resende MB, Zanoteli E, Carvalho MS, Marie SK, Reed UC: Comparison of motor strength and function in patients with Duchenne muscular dystrophy with or without steroid therapy. Arq Neuropsiquiatr 2010, 68:683-688

17. ATS/ERS: American thoracic society/european respiratory society: statement on respiratory muscle testing. Am J Respir Crit Care Med 2002, 166:518-624.

18. Knudson RJ, Slatin RC, Lebowitz MD, Burrows B: The maximal expiratory flow-volume curve. Normal standards, variability, and effects of age. Am Rev Respir Dis 1976, 113:587-600.

19. Alman BA, Raza SN, Biggar WD: Steroid Treatment and the development of scoliosis in males with Duchenne muscular dystrophy. J Bone Joint Surg Am 2004, 86:519-524.

20. Daftary AS, Crisanti M, Kalra M, Wong B, Amin R: Effect of long-term steroids on cough efficiency and respiratory muscle strength in patients with Duchenne muscular dystrophy. Pediatrics 2007, 119(2):e320-e324.

21. Mazzone E, Vasco G, Sormani MP, Torrente Y, Berardinelli A, Messina S, D'Amico A, Doglio L, Politano L, Cavallaro F, Frosini S, Bello L, Bonfiglio S, Zucchini E, De Sanctis R, Scutifero M, Bianco F, Rossi F, Motta MC, Sacco A, Donati MA, Mongini T, Pini A, Battini R, Pegoraro E, Pane M, Gasperini S, Previtali S, Napolitano S, Martinelli D, Bruno C, Vita G, Comi G, Bertini E, Mercuri E: Functional changes in Duchenne muscular dystrophy: a 12month longitudinal cohort study. Neurology 2011, 77(3):250-256.

22. Brito MF, Moreira GA, Hallinam MP, Tufik S: Air stacking and chest compression increase peak cough flow in patients with Duchenne muscular dystrophy. J Bras Pneumol 2009, 39:973-979.

23. Bach JR, Bianchi C, Vidigal-Lopes M, Turi S, Felisari G: Lung insuflation by glossopharyngeal breathing and "air stacking" in Duchenne Muscular Dystrophy. Am J Phys Med Rehabil 2007, 86:295-300.

doi:10.1186/1756-0500-5-435

Cite this article as: Machado et al:: Lung function monitoring in patients with duchenne muscular dystrophy on steroid therapy. BMC Research Notes 2012 5:435

\section{Submit your next manuscript to BioMed Central and take full advantage of:}

- Convenient online submission

- Thorough peer review

- No space constraints or color figure charges

- Immediate publication on acceptance

- Inclusion in PubMed, CAS, Scopus and Google Scholar

- Research which is freely available for redistribution 